\title{
Metode Topsis Untuk Sistem Pendukung Keputusan Penilaian Mall Terbaik Di Kota Depok
}

\author{
Rachman Komarudin ${ }^{1}$, Ali Haidir ${ }^{2}$, Henny Destiana ${ }^{3}$, Yana Iqbal Maulana ${ }^{4}$, Maisyaroh \\ Maisyaroh ${ }^{5,}$
}

${ }^{1}$ Sistem Informasi; Universitas Nusa Mandiri; Jalan. Jatiwaringin Raya No. 2, Cipinang Melayu Makasar, Jakarta Timur 13620, Telp. (021) 8005722; e-mail: rachman.rck@nusamandiri.ac.id

${ }^{2}$ Sistem Informasi; Universitas Bina Sarana Informatika; Jalan Kramat Raya No.98, Kwitang, Jakarta Pusat, 10450, Jakarta, Indonesia; e-mail: ali.alh@bsi.ac.id

${ }^{3}$ Sistem Informasi Akuntansi; Universitas Bina Sarana Informatika Kabupaten Karawang; Jalan Ahmad Yani No.98 Karawang; e-mail: henny.hnd@bsi.ac.id

${ }^{4}$ Teknologi Informasi; Universitas Bina Sarana Informatika; Jalan Kramat Raya No.98, Kwitang, Jakarta Pusat, 10450, Jakarta, Indonesia; e-mail: yana.yim@bsi.ac.id

${ }^{5}$ Teknologi Komputer; Universitas Bina Sarana Informatika; Jalan Kramat Raya No.98, Kwitang, Jakarta Pusat, 10450, Jakarta, Indonesia; e-mail: maysaroh.msy@bsi.ac.id

* Korespondensi: e-mail: maysaroh.msy@bsi.ac.id

Diterima: 02 Desember 2021; Review: 15 Desember 2021; Disetujui: 16 Desember 2021

Cara sitasi: Komarudin R, Haidir A, Destiana H, Maulana Y. I., Maisyaroh M. 2021. Metode Topsis Untuk Sistem Pendukung Keputusan Penilaian Mall Terbaik Di Kota Depok. Bina Insani ICT Journal. Vol. 8 (2): 197-206.

Abstrak: Mall merupakan tempat berbelanja dan refreshing yang sangat disukai banyak kalangan. Selain untuk tempat berbelanja, di mall juga terdapat banyak kuliner, tempat bermain anak, bioskop, dan masih banyak fasilitas hiburan yang ada di mall. Ada banyak mall di Kota Depok seperti Detos, Margo City, CIPLAZ Depok (Ramayana), D'Mall, Pesona Square, ITC Depok, Cinere Bellevue Mall, dan Cimanggis Square. Banyaknya Mall yang ada kerap kali membuat pengunjung bingung untuk menentukan kemana harus pergi kemall yang membuat nyaman dan bisa semua dilakukan. Berangkat dari permasalahan ini maka tujuan penelitian ini dilakukan untuk menentukan Mall terbaik. Ada beberapa kriteria yang digunakan dalam menentukan Mall terbaik yaitu Kebersihan, Keamanan, Tempat parkir, Kelengkapan tenant, Lokasi strategis dan Fasilitas umum. Dalam penelitian ini penulis menggunakan Metode Topsis, metode ini pengambilan keputusan menggunakan multi kriteria dengan prinsip untuk alternaatif yang terpilih memiliki jarak terdekat untuk solusi terbaik positif. Hasil perhitungan didapat bahwa Mall Terbaik di Kota Depok yaitu Margo City dengan nilai 1, untuk rangking kedua yaitu Detos dengan nilai 0,9887, dan rangking ketiga yaitu ITC Depok dengan nilai 0,3246.

Kata kunci: mall, metode Topsis, sistem pendukung keputusan

Abstract: The mall is a place for shopping and refreshing that is very popular among many people. In addition to shopping, in the mall there are also many culinary delights, children's playgrounds, cinemas, and many entertainment facilities in the mall. There are many malls in Depok City such as Detos, Margo City, CIPLAZ Depok (Ramayana), D'Mall, Pesona Square, ITC Depok, Cinere Bellevue Mall, and Cimanggis Square. The number of existing malls often makes visitors confused about where to go to the mall which makes everything comfortable and can be done. Departing from this problem, the purpose of this study was to determine the best Mall. There are several criteria used in determining the best mall, namely Cleanliness, Security, 
Parking, Tenant Completeness, Strategic Location and Public Facilities. In this study, the author uses the Topsis method. This method uses multiple criteria for decision making with the principle that the chosen alternative has the closest distance to the best positive solution. The results of the calculation show that the Best Mall in Depok City is Margo City with a value of 1 , for the second rank is Detos with a value of 0.9887, and the third rank is ITC Depok with a value of 0.3246 .

\section{Keywords: decission support system, mall, Topsis methode}

\section{Pendahuluan}

Unsur-unsur sebuah pusat perbelanjaan terdiri dari departemen store dan rumah makan yang saling berhadapan kekoridor utama dan terjadinya interaksi antar pengunjung dan pedagang [1]. Area pusat bisnis kota dengan pergerakan linier berorientasikan pada pejalan kaki dengan bentuk ruang-ruang interaksi berbentuk pedestrian dengan kombinasi plaza dapat disebut sebagai Pusat perbelajaan Mall [2][3].

Ada banyak mall di Kota Depok seperti Detos, Margo City, CIPLAZ Depok (Ramayana), D'Mall, Pesona Square, ITC Depok, Cinere Bellevue Mall, dan Cimanggis Square. Banyaknya Mall yang ada kerap kali membuat pengunjung bingung untuk menentukan kemana harus pergi kemall yang membuat nyaman dan bisa semua dilakukan. Kurangnya kelengkapan fasilitas umum mall juga dapat menyebabkan sepinya pengunjung mall dan keengganan pengunjung untuk berkunjung ke mall tersebut. Berangkat dari permasalahan ini maka tujuan penelitian ini dilakukan untuk menentukan Mall terbaik.

Untuk menentukan keputusan terbaik dibutuhkan sebuah sistem yang dapat membantu mengambil keputusan untuk menyelesaikan sebuah masalah dan komunikasi yang bersifat semi terstruktur dan tak terstruktur dapat disebut juga sebagai Sistem Penunjang Keputusan (SPK) [4][5].

Dari permasalahan tersebut yang dapat dicarikan solusi bagaimana cara menerapkan Pendukung Keputusan dalam menilai Mall yang terbaik sehingga, dengan adanya penelitian ini pengunjung yang ingin ke mall di Kota Depok dapat mengetahui mall yang terbaik, sebelum mereka mengunjungi mall tersebut. Selain itu tujuan penelitian ini nantinya tidak hanya untuk masyarakat Kota Depok saja tetapi masyarakat yang berada di luar kota depok juga dapat mengetahui mall yang terbaik tanpa harus mengunjungi mall-mall tersebut.

Untuk menyelesaikan masalah tersebut penulis menggunakan metode Topsis untuk mencari solusi terbaik [6], serta dapat menyelesaikan pengambilan keputusan secara ampuh, komputasinya lancar, serta memiliki kemampuan mengukur kinerja relatif dari alternatif-alternatif keputusan [7].

Ada beberapa kriteria yang digunakan dalam menentukan Mall terbaik yaitu Kebersihan didalam maupun di luar mall seperti lobby, toilet, tempat makan, Keamanan didalam maupun di luar mall seperti pos security, Tempat parkir yang disediakan oleh mall baik dibasement maupun luar basement, Kelengkapan tenant dapat berupa food and beverage, department entertainment (karaoke, time zone), fashion, health and beauty, Lokasi strategis yang dapat diakses angkutan umum dan Fasilitas umum seperti tempat ibadah, wifi, smooking area, dan nursing room (ruang menyusui).

\section{Metode Penelitian}

Dalam melakukan penelitian Sistem Pendukung Keputusan Pemilihan Mall yang terbaik di Kota Depok, peneliti melakukan kunjungan ke beberapa mall yang diambil dalam penelitian ini, diantaranya : 1. Mall Detos atau Depok Town Square, 2. Margo City Depok atau Margonda City Depok, 3. Ciplaz Depok (Ramayana), Mall ini juga dikenal dengan Plaza Ramayana Depok, 4.D'Mall Depok atau Depok Mall, 5. Pesona Square, 6. ITC Depok, Mall yang paling sering dikunjungi, karena banyaknya toko yang menjual dengan harga grosir, 7. Cinere Bellevue Mall, dan 8. Cimanggis Square.

Peneliti mendapatkan uraian tentang data responden berdasarkan, jenis kelamin, umur dan mall yang disering dikunjungi responden. Berikut merupakan data penduduk kota depok yang diambil melalui website Badan Pusat Statistik Nasional Republik Indonesia, www.bps.go.id. Data penduduk diambil berdasarkan kelompok umur, daerah perkotaan/perdesaan, dan jenis kelamin. 
Kota Depok

\begin{tabular}{|c|c|c|c|c|c|c|c|c|c|}
\hline \multirow{4}{*}{ Kelompok Umur } & \multicolumn{8}{|c|}{ Klasifikasi Perkotaan/Perdesaan } & \multirow{2}{*}{$\begin{array}{l}\text { Satuan: jiwa } \\
\text { aan }\end{array}$} \\
\hline & \multicolumn{3}{|c|}{ Perkotaan } & \multicolumn{3}{|c|}{ Perdesaan } & \multicolumn{2}{|c|}{ Perkotaan + Perdesaan } & \\
\hline & \multicolumn{3}{|c|}{ Jenis Kelamin } & \multicolumn{3}{|c|}{ Jenis Kelamin } & \multicolumn{3}{|c|}{ Jenis Kelamin } \\
\hline & Laki-laki & Perempuan & $\begin{array}{l}\text { Laki-laki + } \\
\text { Perempuan }\end{array}$ & Laki-laki & Perempuan & $\begin{array}{l}\text { Laki-laki + } \\
\text { Perempuan }\end{array}$ & Laki-laki & Perempuan & $\begin{array}{r}\text { Laki-laki + } \\
\text { Perempuan }\end{array}$ \\
\hline $0-4$ & 88590 & 82278 & 170868 & 0 & 0 & 0 & 88590 & 82278 & 170868 \\
\hline $5-9$ & 84554 & 80022 & 164576 & 0 & 0 & 0 & 84554 & 80022 & 164576 \\
\hline $10-14$ & 73982 & 70451 & 144433 & 0 & 0 & 0 & 73982 & 70451 & 144433 \\
\hline $15-19$ & 71473 & 74525 & 145998 & 0 & 0 & 0 & 71473 & 74525 & 145998 \\
\hline $20-24$ & 77052 & 78417 & 155469 & 0 & 0 & 0 & 77052 & 78417 & 155469 \\
\hline $25-29$ & 87631 & 90134 & 177765 & 0 & 0 & 0 & 87631 & 90134 & 177765 \\
\hline $30-34$ & 88454 & 86937 & 175391 & 0 & 0 & 0 & 88454 & 86937 & 175391 \\
\hline $35-39$ & 81473 & 77453 & 158926 & 0 & 0 & 0 & 81473 & 77453 & 158926 \\
\hline $40-44$ & 68409 & 63228 & 131637 & 0 & 0 & 0 & 68409 & 63228 & 131637 \\
\hline $45-49$ & 51483 & 49398 & 100881 & 0 & 0 & 0 & 51483 & 49398 & 100881 \\
\hline $50-54$ & 39353 & 37399 & 76752 & 0 & 0 & 0 & 39353 & 37399 & 76752 \\
\hline $55-59$ & 28151 & 25063 & 53214 & 0 & 0 & 0 & 28151 & 25063 & 53214 \\
\hline $60-64$ & 16230 & 16656 & 32886 & 0 & 0 & 0 & 16230 & 16656 & 32886 \\
\hline $65-69$ & 12172 & 11391 & 23563 & 0 & 0 & 0 & 12172 & 11391 & 23563 \\
\hline 70-74 & 6671 & 7111 & 13782 & 0 & 0 & 0 & 6671 & 7111 & 13782 \\
\hline 75-79 & 3073 & 3931 & 7004 & 0 & 0 & 0 & 3073 & 3931 & 7004 \\
\hline 80-84 & 1374 & 2019 & 3393 & 0 & 0 & 0 & 1374 & 2019 & 3393 \\
\hline $85-89$ & 476 & 820 & 1296 & 0 & 0 & 0 & 476 & 820 & 1296 \\
\hline $90-94$ & 147 & 335 & 482 & 0 & 0 & 0 & 147 & 335 & 482 \\
\hline $95+$ & 68 & 186 & 254 & 0 & 0 & 0 & 68 & 186 & 254 \\
\hline Jumlah & 880816 & 857754 & 1738570 & 0 & 0 & 0 & 880816 & 857754 & 1738570 \\
\hline
\end{tabular}

sumber: BPJS (2021)

Gambar 1. Lampiran Populasi Kota Depok

Kemudian peneliti membuatkan kerangka penelitian atau tahapan penelitian. Pada gambar tahapan penelitian yang dilakukan dalam penelitian adalah: a. Mengidentifikasi Masalah: peneliti mencari permasalahan-permasalahan yang ada dalam meneliti mall yang terbaik di kota depok, sehingga peneliti mencoba untuk menerapkan metode Topsis dalam masalah ini. Peneliti juga mengambil dari beberapa sampel responden yang mengisi kuesioner yang diberikan, misalkan dari pengalaman pengunjung yang pernah mengunjungi beberapa mall di Kota Depok, b. Perumusan Masalah: kendala dan masalah yang didapat kemudian penulis rumuskan untuk menjadi bahan kajian dalam penelitian pemilihan mall terbaik. Dari isian kuesioner responden, peneliti mengumpulkan masalah yang dialami saat pengunjung mengunjungi beberapa mall yang ada di Kota Depok, c. Menentukan Tujuan Penelitian: yaitu memberikan jalan keluarnya terhadap para pengunjung untuk memilih Mall terbaik. Lalu, menerapkan sistem pendukung keputusan dengan metode Topsis untuk memudahkan pengunjung agar lebih mudah lagi dalam memilih Mall, d. Studi Pendahuluan: pengumpulan data-data dan informasi mengenai data mall yang terkait dengan penelitian, e.Merumuskan Hipotesis: Hipotesis merupakan dugaan sementara yang akan dibuktikan kebenaran melalui penelitian di lapangan. Perumusan hipotesis dilakukan setelah peneliti mendapatkan data isian kuesioner yang diisi oleh responden, f. Studi Literatur: Pada tahap ini, mempelajari literatur yang akan digunakan sebagai kajian dalam penelitian sesuai dengan permasalahan yang terkait dengan pemilihan mall terbaik di Kota Depok. Dan memilih kriteria penilaian serta bobot nilai per kriteria, g. Pengumpulan Data: Pengumpulan data didapat dari pengguna situs ecommerce melalui pengisian kuesioner yang dilakukan dengan metode pengambilan sampel. Dan Metode Topsis sebagai teknik pengolahan data pada penelitian, h. Pengolahan Data: Data dan informasi yang didapat diolah dengan metode Topsis, i. Deskripsikan Hasil Penelitian Tahap ini merupakan tahapan yang terakhir dari uraian yang diproses penelitian dengan menyimpulkan hasil dari penelitian sistem pendukung keputusan dalam memilih Mall 
menggunakan metode Topsis dan memberikan saran sebagai usulan perbaikan terhadap penelitian yang selanjutnya agar lebih baik lagi. Berikut gambar tahapan dalam penelitian ini:

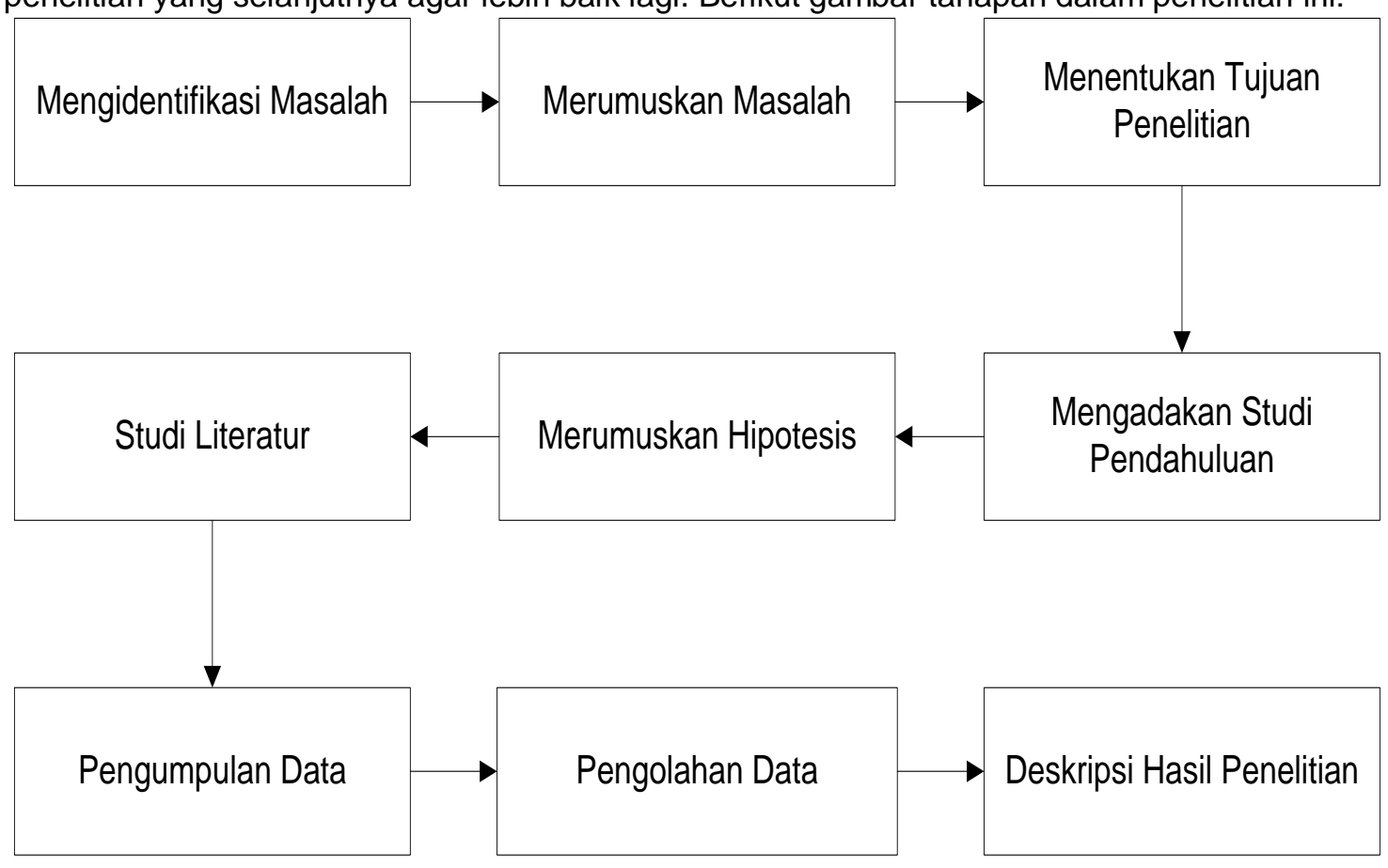

Sumber: Hasil Penelitian (2021)

Gambar 1. Tahapan Penelitian

Tahapan pada penelitian dengan perhitungan metode TOPSIS yang akan dilakukan sebagai berikut: a. Input kriteria penilaian, pada tahap ini peneliti menentukan Kriteria-kriteria yang digunakan sebagai acuan dalam pengambilan kriteria penilaian, b. Input Bobot setiap kriteria, dari krtiteria yang digunakan diberikan bobot nilai, dengan total bobot dari keseluruhan kriteria adalah 1, c. Proses bobot Alternatif, dari Alternatif yang digunakan dihitung nilai prosentase berdasarkan data responden yang digunakan, Total prosentase dari Alternatif yang digunakan adalah $100 \%$, d.Normalisasi Matriks Alternatif setiap kriteria, Pada setiap alternatif Ai pada setiap kriteria Cj yang ternormalisasi, dibutuhkan rating kinerja dengan Nilai ternormalisasi $r i j$, e. Proses preferensi setiap alternative, Menetukan Nilai prefensi untuk setiap alternatif $(V i)$, f. Nilai akhir preferensi, Nilai $V i$ yang lebih besar menentukan bahwa alternatif $A i$ terpilih, g. Hasil Penilaian Terbaik, perangkingan untuk menampilkan nilai Mall terbaik di Kota Depok berdasarkan nilai tertinggi.

Pada metode TOPSIS pengambilan keputusan dengan multi kriteria menggunakan prinsip untuk alternaatif yang terpilih memiliki jarak terdekat untuk solusi ideal positif [8]. Keunggulan metode TOPSIS ini [9]: a. mudah dipahami serta Memiliki konsep yang sederhana, b. Waktu perhitungan yang efisien, c. Dapat mengukur kinerja relatif dari alternatif-alternatif keputusan.

Langkah-langkah sebelum melakukan metode TOPSIS adalah [10]: a. mencari rating kinerja untuk setiap alternatif kriteria, b. mencari bobot nilai untuk setiap kriteria(w). Nilai bobot untuk setiap kriteria harus memiliki rentang nilai yang sama, c. mencari matriks keputusan yang ternormalisasi, d. mencari matriks keputusan yang ternormalisasi terbobot, e. membuat matriks A+ dan matriks A-, f. Menentukan jarak antara nilai setiap ahernatif dengan matriks A+ dan matriks A-, g. mencari nilai preferensi untuk setiap alternatif. Berikut gambar tahapan pengolahan data dengan menggunakan metode TOPSIS dalam penelitian ini: adalah [11]:

Langkah-langkah dalam menyusun algoritma penelitian ini dengan metode Topsis

Menentukan normalisasi matriks keputusan. Nilai ternormalisasi rij dihitung dengan rumus:

$$
r i j=\frac{X i j}{\sqrt{\sum^{m} x^{2} i j}}
$$


BINA INSANI ICT JOURNAL ISSN: 2355-3421 (Print) ISSN: 2527-9777 (Online); 197 - 206

$\mathrm{i}=1$

Keterangan: $i=1,2, \ldots, \mathrm{m}$;

$j=1,2, \ldots, \mathrm{n}$.

Sumber: Hasil Penelitian (2021)

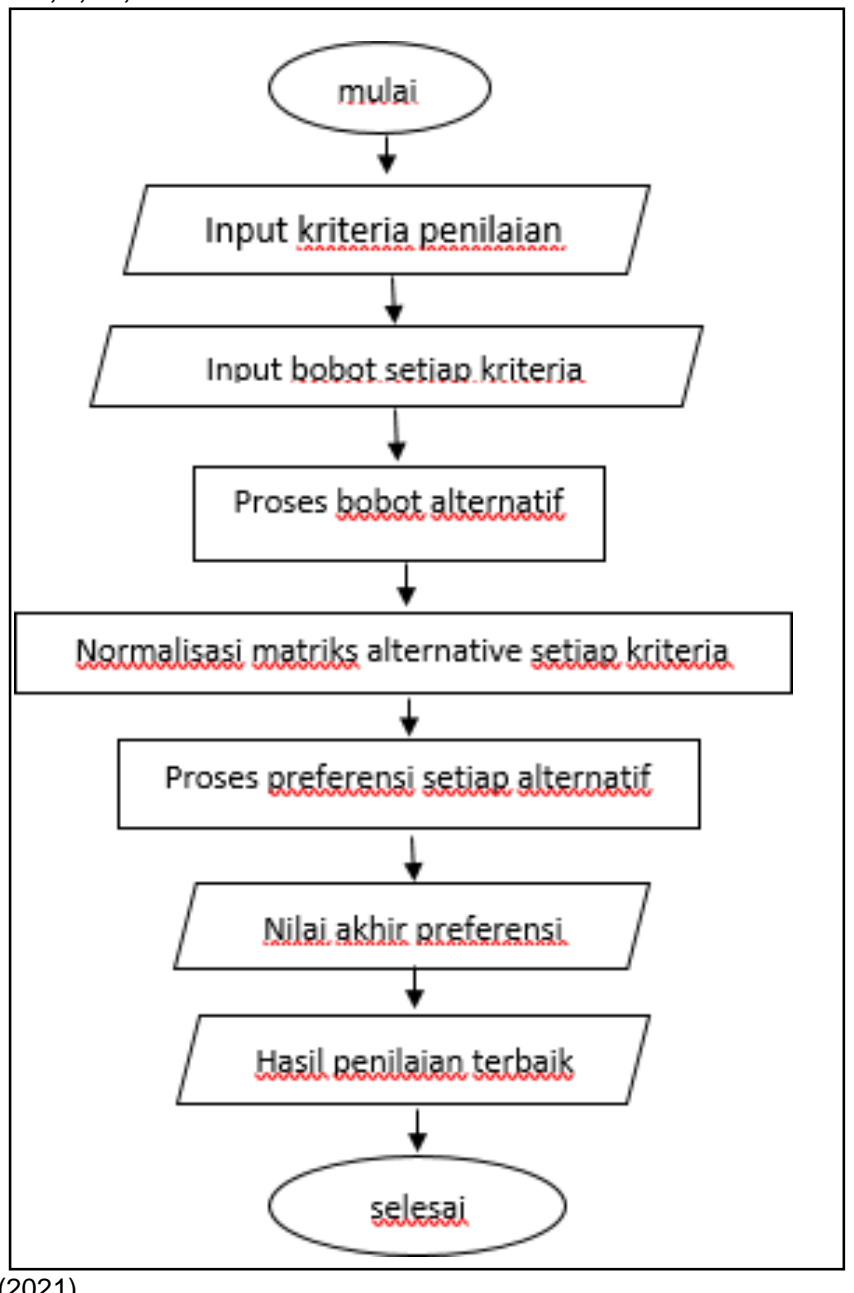

Gambar 2. Tahapan Pengolahan Data dengan Metode Topsis

Menentukan bobot ternormalisasi matriks keputusan. Nilai bobot ternormalisasi $y i j$ sebagai berikut:

$$
y i j=w i j r i j
$$

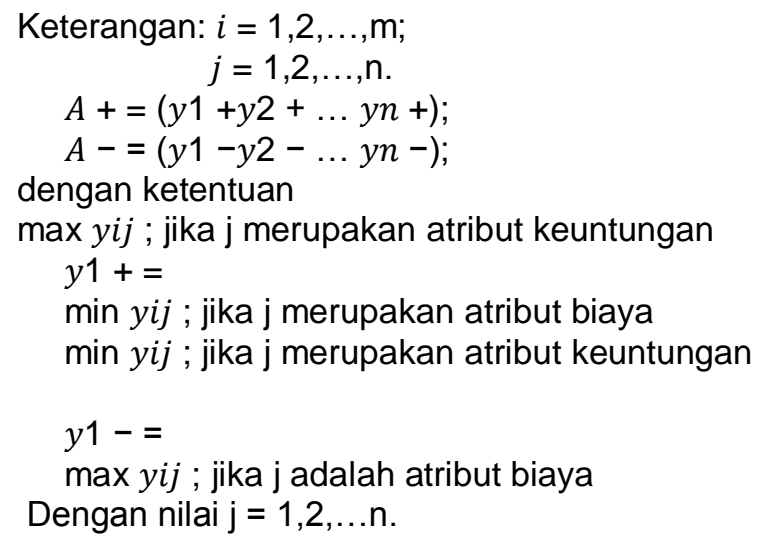


Jarak antara alternatif $A i$ antara solusi terbaik positif dapat dirumuskan:

$D^{+}=\sqrt{\sum_{i j=1}^{n}\left(y_{i}^{+}-y_{i j}\right)^{2}}$

Keterangan: $i=1,2, \ldots, \mathrm{m}$.

Jarak antara alternatif $A i$ antara solusi terbaik negative dapat dirumuskan:

$D_{i}^{-}=\sqrt{\sum_{j=1}^{n}\left(y_{i j}-y_{i}\right)^{2}}$

Dengan $\mathrm{i}=1,2, \ldots, \mathrm{m}$.

Nilai prefensi untuk setiap alternatif $(V i)$ diberikan sebagai:

$V_{t}=\frac{D^{-}}{D_{i}^{-}+D_{i}^{+}} ;$

dengan $\mathrm{i}=1,2, \ldots \mathrm{m}$.

Nilai $V i$ yang lebih besar menentukan bahwa alternatif $A i$ terpilih.

Setelah perhitungan menggunakan nilai preferensi untuk setiap alternatif didapat, maka selanjutnya dilakukan perangkingan untuk menampilkan nilai Mall Terbaik di Kota Depok berdasarkan nilai tertinggi. Berikut merupakan alternatif dan kriteria yang dipakai untuk menentukan Mall Terbaik di Kota Depok dengan menggunakan metode Technique For Order Performance by Similarity to Ideal Solution (TOPSIS), yaitu: a) Alternatif: DETOS (A1), Margo City (A2), CIPLAZ Depok (A3), D'MALL (A4), Pesona Square (A5), ITC Depok (A6), Cinere Bellevue Mall (A7), Cimanggis Square (A8), b) Kriteria: C1 (Kebersihan), C2 (Keamanan), C3 (Tempat Parir), C4 (Kelengkapan Tenant), C5 (Lokasi Strategis), C6 (Fasilitas Umum).

\section{Hasil dan Pembahasan}

Responden merupakan pengunjung yang sebelumnya pernah berkunjung ke mall yang dia kunjungi, dengan menyebarkan kuesioner di kawasan Kota Depok Jawa Barat sebanyak 51 kuesioner. Peneliti mengumpulkan data kuesioner dilakukan kurang lebih selama 5 (lima) hari. Peneliti mendapatkan uraian tentang data responden berdasarkan, jenis kelamin, umur dan mall yang disering dikunjungi responden. Maka dari itu, hasil pengumpulan data yang penulis dapatkan adalah sebagai berikut: a) Jenis kelamin didapat data: jenis kelamin laki-laki ada 17 responden dengan prosentase $66,7 \%$, dan perempuan ada 34 responden dengan prosentase $33,3 \%$, dari total 51 responden, b) Umur didapat data: Usia 15-20 tahun dengan jumlah 12 responden dengan prosentase $23,5 \%$, usia $21-25$ tahun dengan jumlah 27 responden dengan prosentase 52,9\%, usia 26-30 tahun dengan jumlah 7 responden dengan prosentase $13,7 \%$, usia 31-35 tahun dengan jumlah 3 responden dengan prosentase 5,9\%, usia $>35$ tahun dengan jumlah 2 responden dengan prosentase $3,9 \%$.

\section{Uraian Hasil Instrumen Penelitian}

Berikut merupakan hasil kuesioner yang telah disebar berdasarkan penilaian oleh responden, yaitu:

Tabel 1. Hasil data pernyataan kuesioner

\begin{tabular}{|c|c|c|c|c|c|c|}
\hline Nama Responden & C1 & $\mathrm{C} 2$ & C3 & C4 & C5 & C6 \\
\hline $\mathrm{A} 1$ & 5 & 4 & 5 & 2 & 5 & 4 \\
\hline $\mathrm{A} 2$ & 4 & 4 & 3 & 5 & 2 & 4 \\
\hline A3 & 4 & 5 & 4 & 4 & 5 & 3 \\
\hline A4 & 5 & 4 & 5 & 5 & 5 & 5 \\
\hline A5 & 5 & 3 & 3 & 5 & 2 & 5 \\
\hline A6 & 3 & 3 & 3 & 3 & 3 & 3 \\
\hline A7 & 4 & 4 & 4 & 4 & 4 & 4 \\
\hline A8 & 4 & 4 & 3 & 4 & 5 & 4 \\
\hline A9 & 5 & 5 & 3 & 4 & 5 & 5 \\
\hline A10 & 5 & 5 & 5 & 4 & 5 & 5 \\
\hline
\end{tabular}




\begin{tabular}{|c|c|c|c|c|c|c|}
\hline Nama Responden & C1 & C2 & C3 & C4 & C5 & C6 \\
\hline $\mathrm{A} 11$ & 5 & 5 & 5 & 5 & 5 & 5 \\
\hline A12 & 5 & 5 & 5 & 5 & 5 & 5 \\
\hline A13 & 4 & 3 & 4 & 4 & 5 & 3 \\
\hline A14 & 5 & 5 & 5 & 4 & 5 & 5 \\
\hline A15 & 5 & 5 & 3 & 3 & 4 & 3 \\
\hline A16 & 5 & 5 & 4 & 4 & 3 & 4 \\
\hline A17 & 5 & 5 & 3 & 4 & 3 & 4 \\
\hline A18 & 5 & 4 & 5 & 5 & 5 & 5 \\
\hline A19 & 4 & 2 & 3 & 3 & 5 & 4 \\
\hline A20 & 5 & 5 & 5 & 5 & 5 & 5 \\
\hline A21 & 5 & 5 & 5 & 5 & 5 & 5 \\
\hline A22 & 5 & 5 & 5 & 5 & 5 & 5 \\
\hline A23 & 5 & 3 & 3 & 4 & 5 & 5 \\
\hline A24 & 5 & 4 & 5 & 4 & 3 & 2 \\
\hline A25 & 5 & 5 & 5 & 4 & 5 & 4 \\
\hline A26 & 5 & 4 & 4 & 4 & 4 & 5 \\
\hline A27 & 5 & 5 & 4 & 3 & 5 & 5 \\
\hline A28 & 5 & 5 & 5 & 5 & 5 & 5 \\
\hline A29 & 5 & 5 & 4 & 4 & 5 & 5 \\
\hline A30 & 5 & 5 & 5 & 5 & 5 & 5 \\
\hline A31 & 5 & 5 & 5 & 5 & 5 & 5 \\
\hline A32 & 5 & 5 & 5 & 5 & 5 & 5 \\
\hline A33 & 5 & 5 & 4 & 5 & 4 & 5 \\
\hline A34 & 5 & 5 & 5 & 5 & 5 & 5 \\
\hline A35 & 5 & 5 & 4 & 5 & 4 & 4 \\
\hline A36 & 5 & 4 & 5 & 5 & 5 & 4 \\
\hline A37 & 5 & 5 & 5 & 5 & 5 & 5 \\
\hline A38 & 5 & 5 & 5 & 5 & 5 & 5 \\
\hline A39 & 5 & 5 & 5 & 5 & 5 & 5 \\
\hline A40 & 3 & 3 & 3 & 5 & 4 & 5 \\
\hline A41 & 5 & 4 & 5 & 4 & 4 & 3 \\
\hline A42 & 5 & 5 & 5 & 3 & 5 & 4 \\
\hline A43 & 5 & 5 & 5 & 3 & 3 & 5 \\
\hline A44 & 5 & 5 & 5 & 4 & 5 & 5 \\
\hline A45 & 5 & 5 & 5 & 5 & 5 & 5 \\
\hline A46 & 5 & 5 & 5 & 4 & 4 & 5 \\
\hline A47 & 5 & 5 & 4 & 5 & 5 & 5 \\
\hline A48 & 5 & 5 & 4 & 4 & 5 & 5 \\
\hline A49 & 5 & 5 & 4 & 2 & 1 & 5 \\
\hline A50 & 5 & 5 & 5 & 5 & 5 & 5 \\
\hline A51 & 5 & 5 & 5 & 4 & 2 & 5 \\
\hline
\end{tabular}

Sumber: Hasil Penelitian (2021)

Dari tabel diatas, merupakan hasil pengisian kuesioner dari 51 responden (A1-A51), yang memilih berdasarkan kriteria Mall (C1-C7).

\section{Perhitungan Metode Topsis}

Perhitungan Metode Topsis, yaitu: a) Penilaian Setiap Alternatif, Pada peniliaian setiap alternatif diambil dari data masing-masing setiap mall dengan menghitung dari total responden di setiap kriteria pemilihan mall, b) Daftar Alternatif Mall Terbaik, Setelah dilakukan perhitungan setiap kriteria, maka didapatkan daftar alternatif mall terbaik yang ada di Depok adalah:
DETOS
: 63 (C1), 57 (C2), 61 (C3), 59 (C4), 63 (C5), 58 (C6)
Margo City
: 73 (C1), 72 (C2), 62 (C3), 60 (C4), 68 (C5), 67 (C6)
CIPLAZ Depok (Ramayana)
D'MALL
Pesona Square
18 (C1), 18 (C2), 18 (C3),16 (C4), 16 (C5), 18 (C6)
ITC Depok
: 18 (C1), 18(C2), 15 (C3), 14 (C4), 14 (C5), 18 (C6)
Cinere Bellevue Mall
Cimanggis Square
: 30 (C1),24 (C2), 26 (C3), 27 (C4), 23 (C5), 28 (C6)
: 29 (C1), 29(C2), 27 (C3), 29 (C4),26 (C5), 28 (C6)
: 9 (C1), 9 (C2), 9 (C3), 9 (C4), 9 (C5), 9 (C6)
: 5 (C1), 5 (C2), 5 (C3), 4 (C4), 5 (C5), 5 (C6)

c) Bobot Kriteria Mall Terbaik, diketahui bobot tiap kriteria yaitu : Kriteria : C1 (Kebersihan) 0.20, C2 (Keamanan) 0.08, C3 (Tempat Parir) 0.08, C4 (Kelengkapan Tenant) 0.37, C5 (Lokasi Strategis) 0.06, C6 (Fasilitas Umum) 0.22 dengan total Bobot keseluruhan ktiteria adalah 1, d) Membuat matriks keputusan ternormalisasi terbobot. 


$$
r i j=\frac{x i j}{\sqrt{\sum_{i}^{m} x i j^{2}}}
$$

Hasil perhitungan data normalisasi dijelaskan pada tabel 2.

Tabel 2. Hasil Perhitungan Data Normalisasi

\begin{tabular}{lcccccc}
\multicolumn{1}{c}{ Nama Alternatif } & C1 & C2 & C3 & C4 & C5 & C6 \\
\hline DETOS & 0.580 & 0.554 & 0.622 & 0.615 & 0.619 & 0.575 \\
\hline Margo City & 0.672 & 0.699 & 0.632 & 0.626 & 0.668 & 0.664 \\
\hline CIPLAZ Depok & 0.166 & 0.175 & 0.183 & 0.167 & 0.157 & 0.178 \\
\hline D'MALL & 0.166 & 0.175 & 0.153 & 0.146 & 0.138 & 0.178 \\
\hline Pesona Square & 0.276 & 0.233 & 0.265 & 0.281 & 0.226 & 0.278 \\
\hline ITC Depok & 0.267 & 0.282 & 0.275 & 0.302 & 0.255 & 0.278 \\
\hline Cinere Bellevue Mall & 0.083 & 0.087 & 0.092 & 0.094 & 0.088 & 0.089 \\
\hline Cimangis Square & 0.046 & 0.049 & 0.051 & 0.042 & 0.049 & 0.050 \\
\hline Sumber: Hasil Penelitian $(2021)$ & & & & & &
\end{tabular}

Sumber: Hasil Penelitian (2021)

e) Membuat Matriks keputusan yang ternormalisasi terbobot $\mathrm{V}$.

$$
V_{i j}=w_{i} r_{i j}
$$

3.

Hasil perhitungan matriks keputusan yang ternormalisasi bobot $\mathrm{V}$ dijelaskan pada tabel

Tabel 3.Hasil Perhitungan Matriks Keputusan ysang Ternormalisasi Bobot V

\begin{tabular}{lllllll}
\multicolumn{1}{c}{ Nama Alternatif } & C1 & C2 & C3 & C4 & C5 & C6 \\
\hline DETOS & 0.1138 & 0.0434 & 0.0488 & 0.2292 & 0.0364 & 0.1240 \\
\hline Margo City & 0.1318 & 0.0548 & 0.0496 & 0.2330 & 0.0393 & 0.1433 \\
\hline CIPLAZ Depok & 0.0325 & 0.0137 & 0.0144 & 0.0621 & 0.0092 & 0.0385 \\
\hline D'MALL & 0.0325 & 0.0137 & 0.0120 & 0.0544 & 0.0081 & 0.0385 \\
\hline Pesona Square & 0.0542 & 0.0183 & 0.0208 & 0.1049 & 0.0133 & 0.0599 \\
\hline ITC Depok & 0.0524 & 0.0221 & 0.0216 & 0.1126 & 0.0150 & 0.0599 \\
\hline Cinere Bellevue Mall & 0.0163 & 0.0069 & 0.0072 & 0.0350 & 0.0052 & 0.0192 \\
\hline Cimanggis Square & 0.0090 & 0.0038 & 0.0040 & 0.0155 & 0.0029 & 0.0107 \\
\hline
\end{tabular}

Sumber: Hasil Penelitian (2021)

f) Menentukan matriks solusi ideal positif dan matriks solusi ideal negatif berdasarkan rating bobot ternormalisasi.

$$
\begin{aligned}
& A+=(Y 1+, Y 2+\ldots . Y n+) \\
& A-=\left(Y 1-, Y 2-\ldots . Y n^{-}\right)
\end{aligned}
$$

Berdasarkan data pada tabel 3 hasil perhitungan matriks keputusan yang ternormalisasi Bobot $\mathrm{V}$ maka didapat:

$\mathrm{A}+\quad: 0.1318$ (C1), 0.0548 (C2), 0.0496 (C3), 0.2330 (C4), 0.0393 (C5), 0.1433 (C6)

A- $\quad: 0.0090$ (C1), 0.0038 (C2), 0.0040 (C3), 0.0155, (C4), 0.0029 (C5), 0.0107 (C6)

g) Jarak antara alternatif $\boldsymbol{A}_{\boldsymbol{i}}$ dengan solusi ideal positif.

$$
\begin{aligned}
& D i+=\sqrt{ } \sum\left(Y i j^{-} Y i^{-}\right) 2 \\
& D i^{-}=\sqrt{ } \sum\left(Y i j^{-} Y i^{-}\right) 2
\end{aligned}
$$

Hasil perhitungan data normalisasi dapat di lihat pada tabel 4 hasil perhitungan.

Tabel 4. Hasil Perhitungan Jarak Solusi Ideal Positif dan Ideal Negatif

\begin{tabular}{lcc}
\hline \multicolumn{1}{c}{ Nama Alternatif } & $\boldsymbol{D i}^{+}$ & $\boldsymbol{D i}^{-}$ \\
\hline DETOS & 0.0292 & 0.2723 \\
\hline Margo City & 0 & 0.2932 \\
\hline CIPLAZ Depok & 0.2321 & 0.0612 \\
\hline D'MALL & 0.2384 & 0.0550 \\
\hline Pesona Square & 0.1796 & 0.1142 \\
\hline ITC Depok & 0.1738 & 0.1205 \\
\hline Cinere Bellevue Mall & 0.2706 & 0.0230 \\
\hline Cimanggis Square & 0.2932 & 0 \\
\hline Sumber: (Hasil Penelitian & & 0 \\
\hline
\end{tabular}

Sumber: (Hasil Penelitian, 2021) 
h) Nilai preferensi untuk setiap alternatif $(\boldsymbol{V} \boldsymbol{i})$

$$
V_{i=} \frac{D_{i}-}{\mathrm{D}_{\mathrm{i}}-+\mathrm{D}_{\mathrm{i}}+}
$$

Tabel 5. Hasil Perhitungan Nilai Preferensi Untuk Setiap Alternatif

\begin{tabular}{lcc}
\hline \multicolumn{1}{c}{ Nama Alternatif } & VI & RANGKING \\
\hline DETOS & 0.9887 & 2 \\
\hline Margo City & 1 & 1 \\
\hline CIPLAZ Depok & 0.0650 & 5 \\
\hline D'MALL & 0.0505 & 6 \\
\hline Pesona Square & 0.2878 & 4 \\
\hline ITC Depok & 0.3246 & 3 \\
\hline Cinere Bellevue Mall & 0.0071 & 7 \\
\hline Cimanggis Square & 0 & 8 \\
\hline Sumber: (Hasil Penelitian, 2021) & &
\end{tabular}

Sumber: (Hasil Penelitian, 2021)

Hasil akhir perhitungan nilai preferensi untuk setiap alternatif yang ada pada Tabel 5 Hasil Perhitungan, menyatakan bahwa Mall Terbaik di Kota Depok yaitu Margo City dengan nilai 1, untuk rangking kedua yaitu Detos (Depok Town Square) dengan nilai 0,9887, dan rangking ketiga yaitu ITC Depok dengan nilai 0,3246.

\section{Kesimpulan}

Responden adalah pengunjung yang pernah mengunjungi mall dengan menyebarkan koesioner kepada responden di daerah Kota Depok Jawa Barat sebanyak 51 kuesioner. Pengumpulan data kuesioner ini dilakukan kurang lebih selama 5 (lima) hari. Didapatnya uraian mengenai data responden tersebut dengan berdasarkan, jenis kelamin, umur, dan Mall yang sering dikunjungi. Maka dari hasil pengumpulan data ini yang didapat adalah: a) Dengan sistem ini pendukung keputusan metode Topsis dalam memilih mall terbaik yang diharapkan dapat membantu pengunjung yang merasa bingung atau kesulitan dalam memilih mall yang terbaik, b) Dengan metode Topsis ini, pemilihan mall dapat dilakukan dengan cara efektif dan berdasarkan kriteria-kriteria yang telah ditetapkan. Dengan kriteria yang sudah ditetapkan, hasil dari perhitungan tersebut menggunakan metode Topsis dalam menentukan mall terbaik yang pertama adalah Margo City dengan nilai 1, untuk rangking kedua yaitu Detos (Depok Town Square) dengan nilai 0,9887, dan rangking ketiga yaitu ITC Depok dengan nilai 0,3246.

\section{Referensi}

[1] H. Warouw and F. Mastutie, "Mall Dan Hypermarket Di Kotamobagu (Implementasi Copying Behavior Menurut P A Bell Dalam Arsitektur)," Jurnal Arsitektur Daseng Unsrat Manado, vol. 2, no. 3, pp. 1-9, 2019.

[2] E. B. Polii, P. H. Gosal and J. V. Rate, "Shopping Mall Di Amurang," Jurnal Arsitektur, vol. vol. 8, no. 2, pp. 830-839, 2019.

[3] G. T. Sari, "Pusat Perbelanjaan Mall Di Kabupaten Kubu Raya," JMARS : Jurnal Mosaik Arsitektur, vol. Vol 5, no. 3, pp. 1-12, 2017.

[4] R. Hidayatullah, Artist, "Sistem Penunjang Keputusan Pemilihan Karyawan Terbaik pada PT. Kreasi Inspirasi Sahabat dengan Menggunakan Simpe Additive Weighting (SAW)," Universitas Nusa Mandiri, 2020.

[5] T. Limbong, M. Muttaqin, A. Iskandar, A. P. Windarto, J. Simarmata, M. Mesran, O. K. Sulaiman, D. Siregar, D. Nofriansyah, D. Napitupulu and A. Wanto, Sistem Pendukung Keputusan, Medan: Yayasan Kita Menulis, 2020.

[6] H. F. Indra, A. Gunawan and R. Faiza, "Sistem Pendukung Keputusan Penentuan Karyawan Terbaik," in Seminar Nasional Teknologi Informasi dan Komunikasi (SENTIKA) 2016, Yogyakarta, 2016.

[7] A. C. Ahmad and C. M. Alif, "Kombinasi Metode AHP Dan TOPSIS Pada Sistem Pendukung Keputusan," in Prosiding SNATIF, 2017.

[8] N. Dicky, Konsep Data Mining Vs Sistem Pendukung Keputusan, Yogyakarta: Deepublish, 2015.

[9] Diana, Metode dan Aplikasi Sistem Pendukung Keputusan, 1st ed, Yogyakarta: Deepublish, 2018. 
[10] S. Febrina, Metode Dalam Pengambilan Keputusan, Yogyakarta: Deepublish, 2018.

[11] S. Melati, S. Suhada and D. Rafiqa, "Sistem Pendukung Keputusan Menentukan Obat Diabetes Terbaik Menggunakan Metode Topsis," in Konferensi Nasional Teknologi Informasi dan Komputer (KOMIK), Medan, 2019.

[12] BPJS. Kota Depok Dalam Angka 2019. Jakarta: Badan Pusat Statistik Kota Depok, 2019. 